\title{
KINERJA DAPAT MENINGKATKAN PENDAPATAN UNTUK PENINGKATAN EKONOMI KELUARGA MENURUT PERSPEKTIF ISLAM
}

\author{
Bakti Toni Endaryono $^{1)}$, Arman Paramansyah ${ }^{2)}$, Tjipto Djuhartono ${ }^{3)}$ \\ ${ }^{1,2}$ Ekonomi Syariah STEI Bina Cipta Madani \\ ${ }^{3}$ Program Studi Pendidikan Ekonomi, Universitas Indraprasa PGRI \\ baktitoni@gmail.com ; Paramansyah.aba@gmail.com; \\ tjiptodjuhartono@gmail.com
}

Diterima: Februari 2018; Disetujui: Maret 2018; dipublikasikan: April 2018

\begin{abstract}
ABSTRAK
Peran kinerja yang baik adalah merupakan suatu kewajiban bagi setiap orang didunia apalagi yang berhubungan dengan pekerjaan untuk merubah kehidupan didunia dengan meningkatkan pendapatan dengan tujuan meningkatkan ekonomi keluarga, dengan mencari rejeki maka tentunya tidak lepas dari hal-hal yang sifatnya halal, karena apa yang didapat dalam bekerja tentunya tidak semua di ridhai oleh Allah maka dengan memiliki kinerja yang baik maka peningkatan penghasilan akan dicapai pula, dari dasar penilaian perusahaan bahwa kinerja yang baik adalah yang selalu mengikuti tata cara atau prosedur sesuai standar yang telah ditetapkan agar tujuan pekerjaan tersebut dapat dicapai sesuai dengan yang diharapkan oleh perusahaan
\end{abstract}

Kata Kunci: Peran kinerja, peningkatan ekonomi

\begin{abstract}
The role of good performance is an obligation for every person in the world especially related to the work to change the life of the world by increasing the income with the aim of improving the family economy, by looking for fortune then certainly not out of halal things, because what is gained in work is certainly not all in ridhai by God then by having a good performance then the increase in income will be achieved also, from the basis of the company's assessment that the good performance is always follow the procedures or procedures according to standards that have been set for the purpose of work can be achieved in accordance with which is expected by the company.
\end{abstract}

Keywords: performance role, economic improvement 


\section{PENDAHULUAN}

Sebagai manusia yang hidup didunia maka diwajibkan untuk beribadah yang salah satunya adalah beribadah dengan berusaha ( bekerja) demi mencapai cita-cita untuk merubah kehidupan didunia dengan mencari rejeki, tentunya tidak lepas dari hal - hal yang sifatnya halal, karena apa yang didapat dalam bekerja tentunya tidak semua di ridhai oleh Allah, untuk itu kita harus memahami dengan hal - hal yang bersifat baik dalam bekerja, Al-Qur'an dan Hadist

..."Mengapa Engkau hendak menjadikan (khalifah) di bumi itu orang yang akan membuat kerusakan padanya dan menumpahkan darah, padahal kami senantiasa bertasbih dengan memuji Engkau dan mensucikan Engkau?”... Q.S. Al Baqarah (2) : 30

Ayat tersebut menunjukkan kesangsian malaikat tentang kemampuan manusia untuk mengelola bumi. Pertanyaan yang sangat wajar mengingat tugas menjadi khalifah di muka bumi bukan merupakan tugas yang mudah, terlebih lagi malaikat mengetahui bagaimana karakter buruk dari manusia.

"Sesungguhnya Kami telah mengemukakan amanat kepada langit, bumi dan gununggunung, maka semuanya enggan untuk memikul amanat itu dan mereka khawatir akan mengkhianatinya, dan dipikullah amanat itu oleh manusia." QS 33:72

akan tetapi keputusan Allah menunjuk manusia sebagai khalifah pasti benar adanya, karena Allah telah menyiapkan sedemikian rupa sehingga bumi seisinya dipersiapkan untuk khalifah yang akan memakmurkannya.

"dan Dia-lah Allah yang menundukkan lautan (untukmu), agar kamu dapat memakan daripadanya daging yang segar (ikan), dan kamu mengeluarkan dari lautan itu perhiasan yang kamu pakai; dan kamu melihat bahtera berlayar padanya, dan supaya kamu mencari (keuntungan) dari karunia-Nya, dan supaya kamu bersyukur." 16:14

Allah juga telah memberikan manusia kapasitas dasar manajerial dalam rangka tugasnya sebagai khalifah. Dalam konteks saat ini kapasitas dasar tersebut dapat dibuktikan dari kaidah manajemen modern yang menyatakan bahwa :

"you cannot success if you cannot manage; you cannot manage what you cannot measure; you cannot measure what you cannot define"

Dalam kaidah tersebut hal yang mendasar dalam rangka bisa mencapai kesuksesan adalah adanya kemampuan untuk mengelola (kemampuan managerial). Kemampuan manajerial tersebut hanya dapat diaplikasikan terhadap hal-hal yang terukur, sedangkan proses pengukuran dapat dilakukan apabila kita mampu untuk mendefinisikan apa yang kita ukur tersebut.

Negara kita adalah termasuk diantara negara yang menjadikan kesejahteraan bangsanya sebagai tujuannya. Rumusan kesejahteraan dituangkan dalam pembukaan Undang-Undang Dasar 1945. komitmen tersebut juga terjabarkan dalam pasal 33 tentang perekonomian nasional dan kesejahteraan social

\section{METODE}

Sedangkan metode dalam penulisan jurnal ini maka digunakanya metode penelitian Empiris (Empirical Research) dimana Penelitian Empiris adalah penelitian terhadap fakta empiris yang diperoleh berdasarkan observasi atau pengalaman. Penelitian empiris umumnya lebih menekankan pada penyelidikan aspek perilaku terhadap opini yang ada . Obyek yang diteliti lebih ditekankan pada kejadian sebenarnya dari pada persepsi orang mengenai kejadian. Studi kasus dan lapangan serta penelitian eksperimen merupakan contoh tipe penelitian ini 


\section{HASIL DAN PEMBAHASAN}

Kinerja menurut Anwar Prabu Mangkunegara (2000 : 67). "Kinerja ( prestasi kerja ) adalah hasil kerja secara kualitas dan kuantitas yang dicapai oleh seseorang pegawai dalam melaksanakan tugasnya sesuai dengan tanggung jawab yang diberikan kepadanya.

Kemudian menurut Ambar Teguh Sulistiyani (2003 : 223) "Kinerja seseorang merupakan kombinasi dari kemampuan, usaha dan kesempatan yang dapat dinilai dari hasil kerjanya. Adapun faktor yang mempengaruhi kinerja adalah menurut Armstrong (1998: 16-17) adalah sebagai berikut: (a) Faktor individu (personal factors). Faktor individu berkaitan dengan keahlian,motivasi,komitmen, (b) Faktor kepemimpinan (leadership factors). Faktor kepemimpinan berkaitan dengan kualitas dukungan dan pengarahan yang diberikan oleh pimpinan, manajer, atau ketua kelompok kerja, (c) Faktor kelompok/rekan kerja (team factors). Faktor kelompok/rekan kerja berkaitan dengan kualitas dukungan yang diberikan oleh rekan kerja , (d) Faktor sistem (system factors). Faktor sistem berkaitan dengan sistem/metode kerja yang ada dan fasilitas yang disediakan oleh organisasi, (e) Faktor situasi (contextual/situational factors). Faktor situasi berkaitan dengan tekanan dan perubahan lingkungan, baik lingkungan internal maupun eksternal.

Berdasarkaan pengertian di atas, maka dapat disimpulkan bahwa kinerja merupakan kualitas dan kuantitas dari suatu hasil kerja (output) individu maupun kelompok dalam suatu aktivitas tertentu yang diakibatkan oleh kemampuan pekerja atau kemampuan yang diperoleh dari proses belajar serta keinginan untuk berprestasi untuk bertujuan meningkatkan pendapatan.

Ada beberapa kriteria untuk dapat meningkatkan kinerja karyawan disuatu perusahaan diantaranya adalah : (1) Jenjang karir, jenjang karir merupakan salah satu yang berkaitan dengan motivasi kerja karena setiap karyawan dalam perusahaan yang selalu diperhatikan dalam karirnya maka sudah otomatis kinerja meningkat walaupun ada perbedaan pendapatan antara karyawan yang lainya, (2) Menjalin keakraban sesame, Perbedaan pendapatan bukan menjadi tolak ukur dalam meningkatkan kinerja tetapi keakraban antara pegawai menjadi penting karena apabila sudah terjalin ikatan kerja dengan teman sekantor dan suasana kerja yang cocok maka akan mambuat nyaman dalam bekerja, (3) Pelatihan dan Training, perlunya perusahaan selalu mengadakan kegiatan pelatihan dan training setiap waktunya dengan tujuan untuk meningkatkan kinerja karyawan, dengan di adakanya pelatihan dan training tersebut diharapkan mampu menambah wawasan berfikir karyawan serta dapat menyegarkan ilmu pendidikan yang sudah dimiliki karyawan, (4) Hak setiap karyawan, berbicara hak adalah salah satu konsen setiap karyawan karena merupakan kewajiban yang harus dipenuhi oleh perusahaan seperti Gaji, kesehatan, Cuti, serta tunjangan - tunjangan yang lain ( tunjangan hari raya ) dan tentunya semua itu sedah tertian dalam PKB (perjanjian kerja bersama ) antara karyawan dengan perusahaan, (5) Reward, Reward merupakan salah satu dari meningkatkan kinerja karena dengan adanya reward yang diberikan perusahaan akan menambah motivasi kerja, reward tersebut dapat diberikan tentunya dengan adanya konsekwensi setiap karyawan untuk dapat bekerja dengan tulus, jujur, tanggung jawab, kualitas serta menghasilkan profit perusahaan sesuai yang telah ditentukan, reward tersebut bisa diberikan berupa, uang, emas atau jalanjalan.

Dalam pandangan ekonomi Islam, kinerja (hasil kerja) terkait dengan segala sesuatu yang telah dilakukan oleh seorang individu relevan dengan standar tertentu dijelaskan dalam ayat dalam Al-Quran diantaranya Suraf Al-Kahfi ayat 87- 88 yang berbunyi: "Barang siapa berbuat zalim, kami akan menghukumnya, lalu dia dikembalikan kepada Tuhannya, kemudian Tuhan mengazabnya dengan azab yang sangat keras. Adapun orang yang beriman dan mengerjakan kebajikan, maka dia mendapat pahala yang terbaik sebagai balasan...."

Pada dasarnya bahwa kinerja yang baik adalah yang selalu mengikuti tata cara atau prosedur sesuai standar yang telah ditetapkan agar tujuan pekerjaan tersebut dapat dicapai sesuai 
dengan yang diharapkan. Sehingga dimana tempat kita bekerja sangatlah wajib untuk memperhatikan dan menilai hasil kinerja kita dengan cara memberikan imbal balik melalui penambahan pendapatan baik melalui Gaji, Transport ataupun tunjangan lain yang telah sesuai dengan aturan yang ada dalam perusahaan setelah itu di capai maka peningkatan ekonomi keluarga meningkat melalui pintu pendapat yang diterimanya

Undang-Undang Nomor 13 tahun 1998 menjelaskan juga tentang arti dari kesejahteraan. Kesejahteraan didefinisikan sebagai suatu tata kehidupan dan penghidupan sosial baik material maupun spiritual yang diliputi rasa keselamatan, kesusilaan, dan ketentraman lahir batin yang memungkinkan bagi setiap warga negara untuk mengadakan pemenuhan jasmani, rohani, dan sosial yang sebaik-baiknya bagi diri, keluarga, serta masyarakat dengan menjunjung tinggi hak dan kewajiban asasi manusia sesuai dengan Pancasila.

Pertumbuhan ekonomi dalam perspektif Islam menurut Yusuf untuk mewujudkan kehidupan yang baik (al-hayat at-taiyibah).[5]

Menurut Dr Abdul Ghani 'Abod : Adams mendefinisikan pertumbuhan ekonomi "Perkembangan atau peralihan yang berterusan, merangkum pengagihan semula sumbersumber kekayaan. Perkembangan dari sudut sejarahnya dari era pertanian kepada era industri dan dari tahap itu kepada era perkhidmatan."[6]

Pertumbuhan ekonomi tentunya tidak lepas dari konsep keadilan, distribusi pendapatan dan kekayaan bagi setiap individu pada seluruh generasi tentunya dengan menghapus riba dan mewajibkan ber zakat. Saat ini perjalanan ekonomi konvensional ternyata banyak yang membuat masyarakat tidak mampu mengikuti perkembangan dikarena keterbatasan pendapatan sehingga sulit untuk memenuhi kebutuhan pokok keluarga, salah satu dari masalah ini adalah keadilan dimana kondisi tersebut mendorong masyarakat untuk memperoleh keuntungan yang sebanyak - banyaknya melalui sistem konvensional, sedangkan ekonomi yang berdasarkan islam menganjurkan manusia mengabdi kepada Allah tentunya dilandasi dengan iman dan takwa untuk memperoleh sesuatu berdasarkan prinsip-prinsip islam

Dalam manajemen keuangan keluarga islami harus dilandasi prinsip keyakinan bahwa penentu dan pemberi rezki adalah Allah dengan usaha yang diniati untuk memenuhi kebutuhan keluarga agar dapat beribadah dengan khusyu' sehingga memiliki komitmen dan prioritas penghasilan halal yang membawa berkah dan menghindari penghasilan haram yang membawa petaka. Rasulullah bersabda: "Barang siapa berusaha dari yang haram kemudian menyedekahkannya, maka ia tidak mempunyai pahala dan dosa tetap di atasnya."

Dalam riwayat lain disebutkan: "Demi Allah yang jiwaku ada di tangan-Nya, tidaklah seorang hamba memperoleh penghasilan dari yang haram kemudian membelanjakannya itu akan mendapat berkah. Jika ia bersedekah, maka sedekahnya tidak akan diterima. Tidaklah ia menyisihkan dari penghasilan haramnya itu kecuali akan menjadi bekal baginya di neraka. Sesungguhnya Allah tidak akan menghapus kejelekan dengan kejelekan, tetapi menghapus kejelekan itu dengan kebaikan sebab kejelekan tak dapat dihapus dengan kejelekan pula." (HR. Ahmad) Dan sabdanya: "Daging yang tumbuh dari harta haram tidak akan bertambah kecuali neraka lebih pantas baginya." (HR. Tirmidzi).

Kebahagiaan adalah tujuan utama dalam kehidupan manusia, kebahagiaan itu akan dicapai apabila segala kebutuhan hidup bisa terpenuhi baik secara spiritual maupun secara material, dalam jangka pendek maupun jangka panjang. Dan terpenuhinya kebutuhan material inilah yang disebut dengan sejahtera.

Islam memandang aktivitas ekonomi secara positif. Semakin banyak manusia terlibat dalam aktivitas ekonomi maka akan semakin baik, sepanjang tujuan dan prosesnya sesuai dengan ajaran islam. Islam memposisikan kegiatan ekonomi sebagai salah satu aspek penting dalam mendapatkan kemulian (falah) dan karenanya kegiatan ekonomi sebagaimana kegiatan lainnya perlu dituntun dan dikontrol agar berjalan seirama dengan ajaran islam secara keseluruhan. 
Disini secara sederhana Maslahah dapat diaertikan sebagai segala bentuk keadaan, baik material maupun non material, yang mampu meningkatkan kedudukan manusia sebagai makhluk yang paling mulia. Sedangkan maslahah dalam ekonomi islam yaitu kesejahteraan umum yaang dapat diartikan segala sesuatu yang bermanfaat bagi masyarakat untuk kepentingan bersama dan menolak kemudhorotan, seperti halnya adanya lembaga-lembaga keuangan yang berbasis syari'ah, seperti halnya Bank Syari'ah, dalam kondisi di jaman sekarang banyak masyarakat yang membutuhkan bank syari'ah agar tercapainya kesejahteraan, bank syari'ah ini menajadi jalan untuk menolong masyarakat seperti transfer, meminjamkan uang, untuk kredit, dan juga menabung.

Dalam ekonomi islam, maslahah dibagi menjadi beberapa maacam, seperti : (1) Almaslahah al-mu'tabarah, yaitu kemaslahatan yang menjadi rujukan dan tidak diragukan arena sudah ditelusuri dalam dalil-dalil sepeerti dalam QS. Al-baqarah melarang kita memberi kemudhorotan dan sperti halnya kamu menganiayanya dalam Al-quran tersebut sudah jelas supaya menjauhi kemudhorotan supaya kita selalu berusaha untuk menjadi orang yang bermanfaat, (2) Al-Maslahah al-mughah, yaitu kemaslahatan yang tida diterima dalam karena melanggar dalam dalil-dalil, (3) Al-maslahah al-mursalah Yaitu kemaslahatan yang tidak pula didukung oleh dalil-dalil dan tidak pula dibatalkan oleh dalil-dalil tersebut seperti pendapat yang dikemukaan dari ulama' terdahulu tentang maslahah.

Selain itu juga dalam bukunya Ahmad Ifham Sholihin disebutkan beberapa pembagian maslahah yaitu, (1) Maslahah Dharuriyyah yaitu kemaslahatan yang diperoleh manusia dalam bentuk terpeliharanya survivalitas hidupnya. Jika kemaslahatan tersebut tidak diperoleh, kehidupan manusia akan mengalami kehancuran. Kemaslahatan tersebut tida akan terpenuhi, kecuali jika hukum islam tersebut diterapkan, (2) Maslahah Hajiyyah, yaitu kemaslahatan yang diperoleh manusia dalam kondisi yang berkaitan dengan keringanan yang diberikan oleh Allah epada manusia. Misalnya ketika sedang melakukan puasa ramadhan atau puasa wajib yang lain, sedangkan pada waktu yang sama sedang bepergian atau sakit, maka orang tersebut diizinkan untuk membatalkan puasanya kemudian diganti dengan puasa pada watu yang lain. Jika orang tersebut sakit yang menyebabkannya tidak bisa duduk atau berdiri, dia dibolehkan sholat dengan berbaring, (3) Maslahah Tahsiniyyah, yaitu kemaslahatan yang diperoleh oleh manusia ketika melaksanakan hukum-hukum yang berkaitan dengan sifat, ahlak dan adab. Misalnya menjaga kebersihan badan dan pakaian. Dan menjada agar hanya makan makanan yang dihalalkan oleh Allah Swt atau menjaga diri terhadap hal-hal yang bisa menjatuhkan martabat kepribadian islam.

Adapun sifat-sifat maslahah sebagai berikut: (a) Maslahah bersifat subyetif dalam arti bahwa setiap individu menjadi hakim bagi masing-masing dalam menentukan apakah suatu perbuatan merupakan suatu Maslahah atau bukan bagi dirinya. Misalnya bila seseorang mempertimbangkan bunga ban memberi maslahah bagi diri dan usahanya, namun syari'ah telah menetapkan keharaman bunga bank, maka penilaian individu menjadi gugur, (b) Maslahah orang per seorang akan konsisten dengan maslahah orang banyak. Konsep ini sangat berbeda dengan konsep pareto optimum, yaitu keadaan optimal dimana seseorang tidak dapat meningkatkan tingkat kepuasan dan kesejahteraan orang lain, (c) Konsep maslahahmendasari semua aktivitas ekonomi dalam masyarakat, baik itu produksi, konsumsi, maupun dalam pertukaran dan distribusi.

Falah, yaitu kemuliaan, kemenangan, kesuksesan. Falah dalam ekonomi islam yaitu tujuan hidup manusia yang diawa oleh islampada dasanya setiap makhluk hidup menginginkan kesejahteraan dan untuk mencapai tahap ini manusia harus mengenal apa maslahah yang terjadi disekitarnya.

Adapun faktor yang bisa mencapai maslahah antara lain; (a) Kebutuhan dan keinginan, jika suatu kebutuhan diinginkan oleh seseorang, maka pemenuhan kebetuhan tersebut akan melahirkan maslahah sekaligus kepuasan, namun jika pemenuhan tidak dilandasi oleh 
keinginan, maka hanya akan memberikan manfaat semata, (b) Maslahah dan kepuasan, (c) Maslahah dalam nilai-nilai ekonomi islam, (d) Perekonomian islam akan terwujud jika prinsip dan nilai-nilai islam diterapkan secara bersama-sama. Penerapan prinsip yang tanp diikuti oleh pelaksanaan nilai-nilai islam hanya akan meberikan manfaat (maslahah duniawi), sedangkan pelaksanaan sekaligus prinsip dan nilai akan melahirkan manfaat dan berkah atau maslahah dunia akhirat.

Dalam maslahah ini tentunya tidak lepas dari kesejaheraan. Seorang ulama besar, Imam Al-Ghazali, telah memberikan sumabngan yang besar dalam pengembangan dan pemikiran dalam dunia islam. Sebuah tema yang menjadi pangkal tolak sepanjang karya-karyanya adalah konsep maslahah atau kesejahteraan sosial atau utilitas. Menurut Ghazali kesejahteraan (maslahah) dari suatu masyarakat tergantung pada pencarian dan pemeliharaan lima tujuan dasar, yaitu : Agama (Ad-dien), hidup atau jiwa (Nafs), keluarga atau keturunan (nasl), harta atau kekayaan (maal), intelektul (aql).

Al-Ghazali memandang perkembangan ekonomi sebagai bagian dari tugas-tugas kewajiban sosial (fard kifayah yang sudah ditentukan Allah. Jika hal ini tidak dipenuhi, kehidupan dunia akan rutih dan kemanusiaan akan binasa. Dan ia bersikeras bahwa pencarian hal-hal ini harus dilakukan secara efisien, karena perbuatan demikian merupakan bagian dari pemenuhan tugas keagamaan seseorang. Selanjutnya ia mengidentifikasikan tiga alasan menapa seseorang hrus melakukan aktiitas ekonomi ? yang pertama untuk mencukupi kebutuhan hidup, yang kedua mensejahterakan keluarga, dan yan ketiga membantu orang lain yang mebutuhkan.

Dan ada juga beberapa prinsip konsumsi dalam islam: prinsip keadilan, prinsip kebersihan, prinsip kesederhanaan, prinsip kemurahan hati, prinsip moralias.

Falah berasal dari bahasa Arab dari kata kerja aflaha-yuflihuyang berarti kesuksesan, kemuliaan, atau kemenangan. Dalam pengertian literal, falah adalah kemuliaan dan kemenangan dalam hidup. yaitu kemuliaan, kemenangan, kesuksesan. Falah dalam ekonomi islam yaitu tujuan hidup manusia yang dibawa oleh islam, pada dasarnya setiap makhluk menginginkan kesejahteraan dan untuk mencapai tahap ini manusia harus mengenal apa masalah yang terjadi disekitarnya.

Dalam ekonomi, falah ada beberapa macam, seperti : (a) Falah sebagai tujuan hidup, (b) Falah merupakan suatu tujuan yang diinginkan ssemua manusia untuk meraih kesuksesan dalam pekerjaannya, oleh sebab itu falah menjadi salah satu tujuan hidup manusia.

Maslahah dan falah sangat erat hubungannya, maslahah memelihara tujuan syara' untuk meraih manfaat sedangkan falah keinginan untuk mencapai kesejahteraan.

Pada dasarnya tujuan hidup setiap manusia adalah untuk mencapai kesejahteraan, meskipun manusia memaknai kesejhteraan dengan perspektif yang berbeda-beda. Islam memaknai kesejahteraan dengan istilah falah yaitu kesejahteraan holistik dan seimbang antara dimensi material-spiritual, individual-sosial dan kesejahteraan di kehidupan duniawi dan diakhirat. Falah dapat terwujud apabila terpenuhi kebutuhan-kebutuhan hidup manusia secara seimbang sehingga tercipta maslahah.

Maslahah adalah segala sesuatu yang mengandung dan mendatangkan manfaat. Dalam ushul fiqh didenfinisikan sebagai jalbul manfaah wal darul mafsdah (menarik manfaat dan menolak kemadharatan). Sehingga dengan prinsip ini Islam menolak segala aktivitas ekonomi yang mendatangakan mafsadah (kerusakan), karena bertentangan dengan maslahah. Adapun menurut Al-Ghazali, kesejahteraan (maslahah)dari suatu masyarakat tergantung kepada pencarian dan pemeliharaan lima tujuan dasar: agama (al-dien), hidup atau jiwa (nafs), keluarga atau keturunan (nasl), harta atau kekayaan (maal), dan Intelek atau akal (aql). Ia menitikberatkan bahwa sesuai tuntunan wahyu, "kebaikan dunia ini dan akhirat (maslahat aldin wa al-dunya) merupakan tujuan utamanya.

Konsumsi yang islami selalu berpedoman pada ajaran islam. Diantara ajaran yang penting berkaitan dengan konsumsi, misalnya perlunya memerhatikan orang lain. Dalam hadis bahwa 
setiap muslim wajib membagi makanan yang dimasaknya kepada tetangganya yang merasakan bau dari makanan tersebut. Diharamkan pula bagi seorang muslim hidup dalam keadaan serba berkelebihan sementara ada tetangganya yang menderita kelaparan. Hal ini adalah tujuan konsumsi itu sendiri, dimana seorang muslim akan lebih mempertimbangkan maslahahnya. Pencapaian maslahah merupakan tujuan dari syariat islam (maqashid syariah), yang tentu saja harus menjadi tujuan dari kegiatan konsumsi.

Dalam menjelaskan konsumsi, kita mengasumsikan bahwa konsumen cenderung untuk memilih barang dan jasa yang memberikan maslahah maksimum. Hal ini sesuai dengan rasionalitas islami bahwa setiap pelaku ekonomi selalu ingin meningkatkan maslahah yang diperolehnya. Dalam perilaku konsumsi, seorang konsumen akan mempertimbangkan manfaat dan berkah yang dihasilkan dari kegiatan konsumsinya. Konsumen merasakan adanya manfaat suatu kegiatan konsumsi ketika ia mendapatkan pemenuhan kebutuhan fisik atau psikis atau material. Disisi lain berkah akan diperolehnya ketika ia mengonsumsi barang/jasa yang dihalalkan oleh syariat islam. Mengonsumsi yang halal saja merupakan kepatuhan kepada Allah, karenanya memperoleh pahala. Pahala inilah yang kemudian dirasakan sebagai berkah dari barang / jasa yang telah dikonsumsi. Sebaliknya, konsumen tidak akan tidak akan mengonsumsi barang-barang/ jasa yang haram karena tidak mendatangkan berkah. Mengonsumsi yang haram akan menimbulkan dosa yang pada akhirnya akan berujung pada siksa Allah. Jadi mengonsumsi yang haram justru memberikan berkah negatif.

Misalnya, ketika seseorang menonton televisi dipagi hari, maka ia bisa memilih channel mengenai berita politik dan hukum, berita kriminal, film kartun, hiburan musik atau siaran lainnya. Setiap jenis siaran tersebut dirancang untuk mampu memberikan manfaat bagi penontonnya, baik berupa layanan informasi maupun kepuasan psikis.

Tambahan informasi dan kepuasan psikis inilah yang merupakan maslahah duniawi atau manfaat. Disisi lain, kegiatan menonton ini dimungkinkan memberikan berkah yang positif ataupun negatif tergantung dari jenis tontonan dan tujuannya. Misalnya, ketika seseorang menonton berita yang mengungkap cacat (aib) dan keburukan seseorang tanpa tujuanyang benar, berati ia mendorong dilakukannya ghibah yang dilarang oleh islam. Oleh karena itu, ia akan memperoleh dosa (berkah yang negatif ) meskipun ia mendapatkan kepuasan psikis. Namun, jika ia memilih menonton acara televisi yang menayangkan berita yang baik, maka ia akan mendapatkan kedua-duanya, yaitu kepuasan psikis dan berkah sekaligus.

Dengan demikian, tujuan ekonomi islam adalah untuk mewujudkan dan meningkatkan kesejahteraan setiap individu yang akan membawa mereka kepada kebahagiaan di dunia dan akhirat (falah)melalui tata kehidupan yang baik dan terhormat, yang merupakan kebahagiaan hakiki yang diinginkan oleh setiap manusia. Jadi, perhatian utama ekonomi islam adalah bagaimana manusia meningkatkan kesejahteraan material dan spiritual. Sebab aspek spiritual harus bersamaan dengan material, sehingga diperlukan sarana bagi pelaku ekonomi yaitu moralitas.

\section{Konsep Kesejahteraan Menurut Umer Chapra}

Umer Chapra menggambarkan secara jelas bagaimana eratnya hubungan antara Syariat Islam dengan kemaslahatan. Ekonomi Islam yang merupakan salah satu bagian dari Syariat Islam, tujuannya tentu tidak lepas dari tujuan utama Syariat Islam. Tujuan utama ekonomi Islam adalah merealisasikan tujuan manusia untuk mencapai kebahagiaan dunia dan akhirat (falah), serta kehidupan yang baik dan terhormat (al-hayah al-tayyibah).Ini merupakan definisi kesejahteraan dalam pandangan Islam, yang tentu saja berbeda secara mendasar dengan pengertian kesejahteraan dalam ekonomi konvensional yang sekuler dan materialistik.

Secara terperinci, tujuan ekonomi Islam dapat dijelaskan sebagai berikut: (1) Kesejahteraan ekonomi adalah tujuan ekonomi yang terpenting. Kesejahteraan ini mencakup kesejahteraan individu, masyarakat dan negara, (2) Tercukupinya kebutuhan dasar manusia, 
meliputi makan, minum, pakaian, tempat tinggal, kesehatan, pendidikan, keamanan serta system negara yang menjamin terlaksananya kecukupan kebutuhan dasar secara adil dibidang ekonomi, (3) Penggunaansum berdaya secara optimal, efisien, efektif, hemat dan tidak mubazir, (4) Distribusi harta, kekayaan, pendapatan dan hasil pembangunan secara adil dan merata, (5) Menjamin kebebasan individu, (6) Kesamaan hak dan peluang, (7) Kerjasama dan keadilan.

Chapra ingin menegaskan (dengan membuat pemaparan cukup komprehensif terutama atas dasar dan dengan landasan filosofis dan teoritis), bahwa umat Islam tidak usah berpaling ke Timur atau ke Barat dalam mewujudkan kesejahteraan, khususnya dalam bidang ekonomi tetapi berpaling pada Islam. Dia mengamati bahwa banyak negara-negara Islam atau yang berpenduduk mayoritas Islam telah mengambil pendekatan pembangunan ekonomi dari Barat dan Timur, dengan menerapkan system kapitalis, sosialis atau Negara kesejahteraan.

Chapra menekankan bahwa selama negara-negara Muslim terus menggunakan strategi kapitalis dan sosialis, mereka tidak akan mampu, berbuat melebihi negara-negara kapitalis dan sosialis, mencegah penggunaan sumber-sumber daya yang tersedia untuk memenuhi kebutuhan dengan demikian akan ditekan secara otomatis, menjadikannya sulit untuk merealisasikan maqashid meskipun terjadi pertumbuhan kekayaan.

Sementara itu konsep Negara Sejahtera, yang mencoba menggabungkan mekanisme harga dengan sejumlah perangkat lainnya. Terutama pembiayaan kesejahteraan oleh negara untuk menjamin keadilan, pada mulanya menimbulkan sebuah euphoria tetapi yang ternyata tidak. Penambahan pengeluaran untuk sektor publik tidak dibarengi dengan suatu pengurangan ganti rugi dalam klaim-klaim lain atas sumber-sumber, dengan defisit anggaran yang membengkak meskipun telah ditetapkan beban pajak yang berat. Keadaan itu menimbulkan pemakaian sumber-sumber daya semakin memburuk, meningkatkan ketidakseim-bangan internal dan eksternal. Masalah kemiskinan dan ketercabutan tetap ber-lanjut dan bahkan semakin dalam. Kebutuhan-kebutuhan tetap tak terpenuhi. Ketidak adilan justru semakin bertambah. Problem yang dihadapi Negara Sejahtera adalah bagaimana menghapuskan ketidakseimbangan yang diciptakannya. Sistem ini tidak memiliki mekanisme filter yang disepakati selain harga untuk mengatur permintaan secara agregat, dunia hanya bersandar sepenuhnya kepada mekanisme pasar untuk menghapuskan ketidakseimbangan yang ada

\section{SIMPULAN}

Peran kinerja yang baik adalah merupakan suatu kewajiban bagi setiap orang didunia apalagi yang berhubungan dengan pekerjaan untuk merubah kehidupan didunia dengan meningkatkan pendapatan dengan tujuan meningkatkan ekonomi keluarga, tak lepas pula dengan selalu mengikuti tata cara atau prosedur sesuai standar yang telah ditetapkan agar tujuan pekerjaan tersebut dapat dicapai sesuai dengan yang diharapkan

Kinerja ( prestasi kerja ) adalah hasil kerja secara kualitas dan kuantitas yang dicapai oleh seseorang pegawai dalam melaksanakan tugasnya sesuai dengan tanggung jawab yang diberikan kepadanya. Pertumbuhan ekonomi dalam perspektif Islam menurut Yusuf untuk mewujudkan kehidupan yang baik (al-hayat at-taiyibah)

prinsip konsumsi dalam islam: prinsip keadilan, prinsip kebersihan, prinsip kesederhanaan, prinsip kemurahan hati, prinsip moralias. Maslahah dan falah sangat erat hubungannya, maslahah memelihara tujuan syara' untuk meraih manfaat sedangkan falah keinginan untuk mencapai kesejahteraan.

Kebutuhan-kebutuhan tetap tak terpenuhi. Ketidak adilan justru semakin bertambah. Problem yang dihadapi Negara Sejahtera adalah bagaimana menghapuskan ketidakseimbangan yang diciptakannya. Sistem ini tidak memiliki mekanisme filter yang disepakati selain harga 


\section{sosio e-kons}

Volume 10, No. 1, April 2018, pp. $11-19$

e-ISSN: 2502-5449

p-ISSN: 2085-2266

http://journal.lppmunindra.ac.id/index.php/sosio_ekons

untuk mengatur permintaan secara agregat, dunia hanya bersandar sepenuhnya kepada mekanisme pasar

\section{SARAN}

Manajemen Perusahaan harus memberlakukan Reward kepada karyawan secara obyektif, berdasarkan penilaian kinerja sesuai standar operasional prosedur perusahaan yang dilakukan secara perodik. Karyawan diharapkan menjalankan pekerjaan secara professional sesuai setandar operasional prosedur perusahaan agar hasil dapat meningkatkan efektif dan efesien

\section{DAFTAR RUJUKAN}

Al Qur'an Digital

Asifudin, A. Janan. (2004). Etos Kerja Islami. Surakarta: Muhammadiyah University Press.

Barry Cushway, (2005). Manajemen Sumber Daya Manusia (Perencanaan, Analysis, Kinerja, Penghargaan ). Jakarta: PT. Elex Media Komputindo Kelompok Gramedia

B.S. Wibowo, dkk. (2008). "Trustco SHOOT : Sharpening, Our Concept and Tools". Jakarta: PT. Syaamil Cipta Media

Chapra, M. U, (2000). Islam dan Tantangan Ekonomi. Jakarta: Gema Insani Press

Hamidi, L, (2003) Jejak-Jejak Ekonomi Syariah. Jakarta: Senayan Abadi Publising

Pusat Pengkajian dan Pengembangan Ekonomi.(2008). Ekonomi Islam, Jakarta: PT Raja Grafindo Persada.

Chapra, U. (2000). Islam dan Tantangan Ekonomi. Jakarta: Gema Insani Press.

Suprayitno. Eko, (2005). Ekonomi Islam. Jakarta: Graha Ilmu. Cetakan pertama.

Adiwarman, A. K., Ekonomi Mikro Islam. Jakarta: PT. Raja Grafindo Persada, Cet. 8

Sumito, W., Asas-asas Perbankan Islam \& Lembaga-lembaga Terkait. Jakarta: Raja grafindo Persada, Cet. ke 4: p.17

https://www.kompasiana.com/khoiriyahdinihanifah/5a14487fa4b06813a2060c32/konsepkesejahteraan-ekonomi-dalam-perspektif-islam diakses pada tanggal 30 Desember 2017 jam $21.00 \mathrm{Wib}$ 